\title{
The Advanced Collaborative Emissions Study (ACES) of 2007- and 2010-Emissions Compliant Heavy-Duty Diesel Engines: Characterization of Emissions and Health Effects
}

\author{
Maria G. Costantini ${ }^{1} \cdot$ Imad Khalek $^{2}$ • Jacob D. McDonald ${ }^{3}$ • Annemoon M. van Erp ${ }^{1}$
}

Received: 20 May 2016 /Revised: 8 August 2016/Accepted: 31 August 2016/Published online: 19 October 2016

(C) Springer International Publishing Switzerland 2016

\begin{abstract}
In 2001, the US Environmental Protection Agency (EPA) adopted stringent new standards for on-highway heavy heavy-duty diesel engine (HHDDE) emissions of particulate matter (PM) and oxides of nitrogen (NOx) that were to become effective during the 2007-2010 time period. The Advanced Collaborative Emissions Study (ACES) was a cooperative, multiparty effort to characterize the emissions (in Phases 1 and 2) and assess the possible health impacts (in Phase 3) of the new, advanced HHDDE technologies, after introducing them to the market. Phase 1 demonstrated that the regulated emissions from four 2007-compliant engines tested were all below the 2007 standards. Both regulated and unregulated emissions were substantially reduced relative to pre-2007 technology engines, except for nitrogen dioxide $\left(\mathrm{NO}_{2}\right)$ emissions that were higher compared to 2004 technology engines due to the use of diesel oxidation catalyst (DOC) and catalyzed diesel particulate filter (DPF) exhaust aftertreatment technologies. Phase 2 showed another large step in emissions reductions for 2010-compliant diesel engines. The three 2010-compliant engines tested had substantially lower regulated emissions of $\mathrm{NOx}, \mathrm{CO}, \mathrm{NMHC}$, and $\mathrm{PM}$ relative to the emission standards and also relative to the 2007compliant engines. NOx reductions were achieved using ureabased selective catalytic reduction (SCR) and an ammonia
\end{abstract}

Maria G. Costantini

mcostantini@healtheffects.org

1 Health Effects Institute, 75 Federal Street, Suite 1400, Boston, MA 02110, USA

2 Southwest Research Institute, 6220 Culebra Rd, San Antonio, TX 78238, USA

3 Lovelace Respiratory Research Institute, 2425 Ridgecrest Dr SE, Albuquerque, NM 87108, USA oxidation catalyst (AMOX). A wide spectrum of particle and gas phase unregulated emissions species, including $\mathrm{NO}_{2}$, were also reduced relative to 2007-compliant engines and older engines. Phase 3 consisted of an inhalation bioassay in which rats were exposed for their lifetime to the diluted exhaust from one of the 2007-compliant engines tested in Phase 1. Three exhaust dilutions were selected based on the nitrogen dioxide $\left(\mathrm{NO}_{2}\right)$ concentrations to achieve three exposure levels: $4.2 \mathrm{ppm}$ (high-DE exposure), $0.8 \mathrm{ppm}$ (mid-DE exposure), and $0.1 \mathrm{ppm}$ (low-DE exposure) $\mathrm{NO}_{2}$. The control exposure consisted of filtered air. $\mathrm{NO}_{2}$ was chosen because the particle concentrations in the exhaust were too low to set the dilution levels. Exposures were conducted $16 \mathrm{~h} /$ day, 5 days/week. Rats were evaluated histopathologically and for respiratory function, a large number of noncancer endpoints, and genotoxicity, at interim time points up to the final sacrifice at 28 months (males) and 30 months (females). Histopathological analyses found that exposure to exhaust from a 2007-compliant engine produced no tumors or precancerous effects in lungs and no increase in tumor incidence outside the lung, but induced mild epithelial hyperplasia in the central acinus region of the lung, interstitial fibrosis, and bronchiolization at the high exposure level. The lung histologic changes were consistent with previous findings in rats after long-term exposure to $\mathrm{NO}_{2}-\mathrm{a}$ major component of the chamber exposure atmosphere, which is substantially reduced in 2010-compliant engines. The majority of the biological endpoints were unchanged with exposure and little inflammation was observed. In summary, the ACES study shows that emissions from 2007- and 2010compliant HHDDE have been reduced dramatically and that exhaust from a 2007-compliant engine produced no tumors or precancerous effects in rats exposed over their lifetime.

Keywords Heavy-duty diesel engines · Emissions $\cdot$ Rats · Inhalation $\cdot$ Carcinogenicity 


\begin{tabular}{|c|c|}
\hline \multicolumn{2}{|c|}{ Abbreviations } \\
\hline 8-OHdG & 8-hydroxy-deoxyguanosine \\
\hline ACES & Advanced Collaborative Emissions Study \\
\hline $\mathrm{AD}$ & Alveolar duct \\
\hline AMOX & Ammonia oxidation catalyst \\
\hline BSFC & Brake-specific fuel consumption \\
\hline CARB & California Air Resources Board \\
\hline $\mathrm{CH}_{4}$ & Methane \\
\hline $\mathrm{CO}$ & Carbon monoxide \\
\hline $\mathrm{CO}_{2}$ & Carbon dioxide \\
\hline $\mathrm{CRC}$ & Coordinating Research Council \\
\hline CVS & Constant volume sampler \\
\hline DOE & US Department of Energy \\
\hline DOC & Diesel oxidation catalyst \\
\hline DPF & Diesel (exhaust) particulate filter \\
\hline $\mathrm{EC}$ & Elemental carbon \\
\hline EGR & Exhaust gas recirculation \\
\hline EMA & Engine and Truck Manufacturers Association \\
\hline EPA & US Environmental Protection Agency \\
\hline FTP & Federal Test Procedure \\
\hline $\mathrm{g} / \mathrm{bhp}-\mathrm{h}$ & Grams per brake horsepower-hour \\
\hline GWP & Global-warming potential \\
\hline $\mathrm{HC}$ & Hydrocarbon \\
\hline HHDDE & Heavy heavy-duty diesel engine \\
\hline IARC & International Agency for Research on Cancer \\
\hline MY & Model year \\
\hline NAAQS & National Ambient Air Quality Standards \\
\hline $\mathrm{N}_{2}$ & Nitrogen \\
\hline $\mathrm{NH}_{3}$ & Ammonia \\
\hline NMHC & Nonmethane hydrocarbon \\
\hline NO & Nitric oxide \\
\hline $\mathrm{NO}_{2}$ & Nitrogen dioxide \\
\hline NOx & Nitrogen oxides \\
\hline $\mathrm{N}_{2} \mathrm{O}$ & Nitrous oxide \\
\hline $\mathrm{OC}$ & Organic carbon \\
\hline PAHs & Polycyclic aromatic hydrocarbons \\
\hline $\mathrm{PM}$ & Particulate matter \\
\hline РTB & Preterminal bronchiole \\
\hline SCR & Selective catalytic reduction \\
\hline $\mathrm{SO}_{2}$ & Sulfur dioxide \\
\hline TB & Terminal bronchiole \\
\hline ULSD & Ultra-low-sulfur diesel \\
\hline
\end{tabular}

\section{Introduction}

Because of health concerns related to exposure to diesel exhaust (DE) emissions, the US Environmental Protection Agency (EPA) in 2001 adopted stringent new standards for diesel fuel and for on-highway HHDDE emissions [23]. Starting with model year (MY) 2007, as shown in Table 1, these engines were required to meet a new emission standard for PM of $0.01 \mathrm{~g} / \mathrm{hp}-\mathrm{h}$ (a $90 \%$ reduction from the previous standard of $0.1 \mathrm{~g} / \mathrm{hp}-\mathrm{h}$ ) and a phased-in limit for oxides of nitrogen (NOx) of approximately $1.2-1.5 \mathrm{~g} / \mathrm{hp}-\mathrm{h}$ (a $25 \%$ to $40 \%$ reduction from the 2004 limit of $2 \mathrm{~g} / \mathrm{hp}-\mathrm{h}$ ). Starting in 2010, they were required to meet a new stringent standard for $\mathrm{NO}_{\mathrm{x}}$ of $0.2 \mathrm{~g} / \mathrm{hp}-\mathrm{h}$ (90\% lower than 2004 standard). In response, industry developed a combination of advancedtechnology engines, exhaust control systems, and reformulated fuels to meet these stringent standards, which were expected to result in substantially reduced emissions of other exhaust constituents as well.

ACES was a cooperative, multiparty effort funded by multiple government and industry stakeholders to characterize the emissions and assess the possible health impacts of the new, advanced HHDDE technologies after introducing them into the market during the 2007-2010 time period. ACES was designed with input from all stakeholders and the scientific community. The study was conducted in three phases: Phases 1 and 2 involved extensive emission characterizations of production on-highway HHDDEs equipped with control systems designed to meet the 2007 and 2010 standards, respectively. These two phases were conducted at the Southwest Research Institute under oversight agreement with the Coordinating Research Council and its Committees. Phase 3 consisted of the health effects assessment in rodents exposed for a lifetime to exhaust from a randomly selected 2007-technology engine among the ones tested in Phase 1. This work was conducted at the Lovelace Respiratory Research Institute under oversight of the Health Effects Institute and its Committees. Detailed results of the three phases of ACES have been presented in separate peer-reviewed publications. The goal of this paper is to provide a comprehensive and integrated summary of the entire study.

\section{Phases 1 and 2}

In Phase 1, four MY 2007 (2007-compliant) HHDDEs, provided by Caterpillar, Cummins, Detroit Diesel Corporation, and Volvo, were tested on an engine dynamometer $[12,13]$. They were equipped with exhaust gas recirculation (EGR) and a DOC followed by a C-DPF. In Phase 2, three MY 2011 (2010-compliant) diesel engines, provided by Cummins, Detroit Diesel Corporation, and Mack (Volvo Powertrain), were tested $[14,15]$. In addition to the DPF, these engines employed a urea-based SCR catalyst and AMOX, placed downstream of the DPF to control NOx emissions. A schematic representation of the emission controls is seen in Fig. 1. The engines were all brand new but had $125 \mathrm{~h}$ of a manufacturer-run break-in and degreening operation prior to shipping to SwRI for emission testing. In this paper, we refer to the two groups of engines as 2007-technology and 2010technology engines, or 2007 and 2010 engines for brevity. 
Table 1 US EPA Emission Standards (by year of implementation) and average emission rates of regulated pollutants measured in ACES (g/bhp-h, FTP cycle)

\begin{tabular}{|c|c|c|c|c|c|c|}
\hline & \multirow{2}{*}{$\begin{array}{l}1998 \\
\text { Standard }\end{array}$} & \multirow{2}{*}{$\begin{array}{l}2004 \\
\text { Standard }\end{array}$} & \multicolumn{2}{|l|}{ MY 2007} & \multicolumn{2}{|l|}{ MY 2010} \\
\hline & & & Standard & Phase 1 & Standard & Phase 2 \\
\hline PM mass & 0.1 & 0.1 & 0.01 & $0.0014 \pm 0.0007$ & 0.01 & $0.0008 \pm 0.0008$ \\
\hline $\mathrm{CO}$ & 15.5 & 15.5 & 15.5 & $0.48 \pm 0.33$ & 15.5 & $0.5 \pm 0.71$ \\
\hline NOx & 4.0 & 2.0 & 1.2 & $1.09 \pm 0.15$ & 0.2 & $0.078 \pm 0.038$ \\
\hline NMHC & 1.3 & 2.4 & 0.14 & $0.015 \pm 0.024$ & 0.14 & $0.000 \pm 0.000$ \\
\hline
\end{tabular}

MY model year

${ }^{\text {a }}$ Reported as the difference between measured total hydrocarbon (THC) and methane

\subsection{Methods}

For the emission tests, tailpipe exhaust was diluted using a full flow constant volume sampler (CVS) at an average dilution ratio of 20:1 in Phase 1 and between 5:1 and 8:1 in Phase 2 (depending on the engine used). The lower dilution ratio in Phase 2 was chosen to enhance the detection limit of the emissions measurements. Two main test cycles were used for engine testing on a dynamometer: the 20-min Federal Test Procedure (FTP) and the 16-h cycles. The 16-h engine test cycle was developed by researchers led by Nigel Clark at West Virginia University, to more closely represent the realworld operations of modern diesel engines than the test cycles (generally the FTP) used in past long-term studies in rats exposed to exhaust from older (pre-2007) diesel engines [5]. It consists of four repeats of a 4-h segment, each composed of three FTP cycles and four steady-state modes (creep, transient, cruise, and high-speed cruise). Fuel was obtained from a commercial supplier. The sulfur and aromatic content of the fuels used in Phase 1 were $4.5 \mathrm{ppm}$ and $27 \%$, respectively [12]; the corresponding values for Phase 2 were $6.5 \mathrm{ppm}$ and $32 \%$ [14].

In both Phases 1 and 2, a forced regeneration was performed before the start of the three repeated FTP (and hotstart FTP) cycle in order to condition the exhaust and the CVS system and to clean the DPF to a baseline level. In Phase 1, a forced active DPF regeneration was also performed before each of the three repeated 16-h cycles [12]. At least one active regeneration occurred during the normal course of emissions testing for the 16-h cycle. However, in Phase 2, due to the long expected time in-between active regenerations, the forced regeneration was performed only before the start of the first $16-\mathrm{h}$ cycle [14] to increase the probability of capturing an active

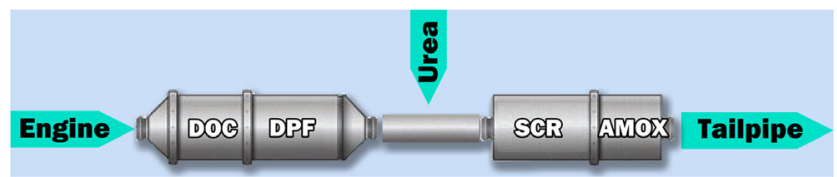

Fig. 1 Schematic representation of diesel engine after treatment technologies. $D O C$ diesel oxidation catalyst, $D P F$ diesel particulate filter, $S C R$ selective catalytic reduction, $A M O X$ ammonia oxidation catalyst. Published with permission from the Health Effects Institute
DPF regeneration during one of the three 16-h repeat tests. However, no active regeneration during the normal course of emissions testing was captured in Phase 2.

The exhaust characterization included regulated emissions of PM, NOx, carbon monoxide (CO), and nonmethane hydrocarbons (NMHC) and unregulated emissions of particle number concentration and size distribution, total hydrocarbons, methane $\left(\mathrm{CH}_{4}\right)$, carbon dioxide $\left(\mathrm{CO}_{2}\right)$, nitric oxide $(\mathrm{NO})$, nitrogen dioxide $\left(\mathrm{NO}_{2}\right)$, nitrous oxide $\left(\mathrm{N}_{2} \mathrm{O}\right)$, ammonia $\left(\mathrm{NH}_{3}\right)$, organic carbon (OC), elemental carbon (EC), metals and elements, inorganic ions, polycyclic aromatic hydrocarbons (PAHs), nitro-PAHs, hopanes, steranes, aldehydes and ketones, dioxins and furans, and many other compounds. In Phase 2, with the advent of the urea-based SCR for NOx control, special attention was also paid to urea and its main decomposition products: $\mathrm{NH}_{3}$ and particle-phase melamine, cyanuric acid, ammelide, ammeline, and biuret. Emission rates from the ACES engines were compared, when possible, with 1998- and 2004-technology engines previously tested at SwRI.

\subsubsection{Sampling and Analysis Methods}

A brief description of the sampling and analysis methods is provided below. More details and information on the measurement range and limit of detection can be found in Khalek et al. [12]. All pollutants were measured during both the FTP cycle and the 16-h cycles. Regulated pollutants were sampled from the CVS. $\mathrm{CO}$ (and $\mathrm{CO}_{2}$ ) were measured using nondispersive infrared detectors, NOx was measured using a heated chemiluminescence detector, and total hydrocarbons (THCs) and $\mathrm{CH}_{4}$ were measured with heated flame-ionization detectors. PM mass was measured gravimetrically on PM collected on a 47-mm Teflon filter. PM mass was also measured continuously using a Dekati DMM-230 analyzer.

Unregulated gaseous pollutants were sampled from the CVS. NO was measured using a heated chemiluminescence detector. $\mathrm{NO}_{2}$ was determined by subtracting $\mathrm{NO}$ from NOx. $\mathrm{N}_{2} \mathrm{O}$ and $\mathrm{NH}_{3}$ were measured by Fourier transform infrared spectroscopy (Phase 2 only). Carbonyls were collected in impingers filled with a solution of dinitrophenylhydrazine 
(DNPH) in acetonitrile and analyzed by high-pressure liquid chromatography. Volatile organic compounds (VOCs) were collected in Tedlar® bags and analyzed by gas chromatography (GC). Particle phase urea and urea-related compounds such as melamine, cyanuric acid, ammelide, ammeline, and biuret were extracted from a TX-40 (Teflon coated borosilicate glass fiber) filter. Each filter was cut into two pieces to separate the acids (cyanuric acid, ammelide, and ammeline) and the bases (urea and melamine). The acid extracts were analyzed by negative atmospheric pressure chemical ionization mass spectrometry (APCI-MS); the base extracts were analyzed by positive APCI-MS.

PM for compositional analyses was also sampled from the CVS, with the exception of PM for EC and OC analyses, which was sampled from an unoccupied animal exposure chamber provided by the Lovelace Respiratory Research Institute. Organic ions and elements were measured on PM collected on Teflon filters by ion chromatography and energydispersive X-ray fluorescence, respectively. EC and OC were measured on PM collected on quartz filters by the thermaloptical method. Particle- and gas-phase semi-volatile organic compounds (such as PAH, oxyPAH, nitroPAH, hopanes/ steranes, higher molecular weight alkanes, cycloalkanes, higher molecular weight aromatics, and certain polar organic compounds) were measured in extracts of PM collected on Teflon filters and in traps containing XAD-4 resin in line with the filter by gas chromatography/mass spectrometry (GC/ MS). PM mass and PM number and size distribution were measured by an engine exhaust particle sizer (EEPS) with a particle size range of 5.6 to $560 \mathrm{~nm}$.

\subsection{Results}

Emissions of all seven 2007 and 2010 engines tested in ACES were (well) below the US EPA standards (see Table 1). In Phase 1, emissions of PM and NOx were 86 and $9 \%$ lower than the 2007 EPA standard, respectively. In Phase 2, NOx emissions were $93 \%$ lower than the 2007 engines' average emissions and $60 \%$ lower than the 2010 NOx standard. NOx emissions consisted primarily of $\mathrm{NO}$ and $\mathrm{NO}_{2}$. In addition, even though the PM standard did not change between 2007 and 2010, emissions of PM in Phase 2 were lower than those from the 2007 engines tested in Phase 1. Emissions of CO and NMHC were also much lower than their respective standards for all engines.

As expected, under the oxidizing conditions prevalent for PM removal in the DOC and DPF in the 2007 engines, over $60 \%$ of the $\mathrm{NO}$ was converted to $\mathrm{NO}_{2}$. As a result, while total emissions of NOx in Phase 1 were lower than the 2004 NOx emission standard (Table 1), the unregulated emissions of $\mathrm{NO}_{2}$ were $33 \%$ higher and the $\mathrm{NO}_{2} / \mathrm{NOx}$ ratio $(0.6)$ was about fivefold higher than observed in a 2004-compliant engine [13]. In Phase 2, however, $\mathrm{NO}_{2}$ emissions were $94 \%$ lower than in Phase 1 (Table 2 and Fig. 2), and lower than those emitted from a 2004-compliant engine, as a result of the use of SCR.

Emissions of $\mathrm{CO}_{2}$, a greenhouse gas and a good indicator of fuel efficiency, were very similar for the two groups of engines (Table 2). Although the engines were not designed to meet the $\mathrm{CO}_{2}$ emission standard that took effect in 2014 (567 g/bhp-h), the results show that ACES engines slightly exceeded or were very close to the 2014 standard. Emissions of the greenhouse gases nitrous oxide $\left(\mathrm{N}_{2} \mathrm{O}\right)$ and methane $\left(\mathrm{CH}_{4}\right)$ were reduced in 2010 engines relative to 2007 engines (Table 2). The investigators used the emissions of $\mathrm{CO}_{2}, \mathrm{~N}_{2} \mathrm{O}$, and $\mathrm{CH}_{4}$ to determine the 100 -year global warming potential (GWP) of the exhaust. GWP is a relative measure of the amount of heat trapped from the instantaneous release of $1 \mathrm{~kg}$ of a trace substance relative to that of $1 \mathrm{~kg}$ of a reference gas. For the purpose of this calculation, $\mathrm{CO}_{2}$ was used as the reference gas (with $\mathrm{GWP}=1$ ), and $\mathrm{CH}_{4}$ emission rate was multiplied by 25 and $\mathrm{N}_{2} \mathrm{O}$ emission rate by 298. GWP was calculated as the sum of these values. The GWP of the two engine technologies was very similar, leading to a $0.1 \%$ increase with the 2010 technology engines (Table 2 and Fig. 2).

Particle number was two orders of magnitude lower in the emissions from 2007-technology engines relative to a 2004compliant engine (similar to the ACES engines, but without aftertreatment) during the FTP cycle $\left(3.94 \times 10^{12} \pm 1.26 \times 10^{12}\right.$ versus $3.04 \times 10^{14} \pm 1.12 \times 10^{13}$ particle/bhp-h). There was also a $41 \%$ reduction in the particle number in the exhaust from Phase 2 2010-technology engines as compared with Phase 1 2007 engines, even though the regulatory requirement did not change. Average FTP emissions from the 2010 engines were $2.31 \times 10^{12} \pm 0.6 \times 10^{12}$ particle/bhp-h.

The particle number in 2007 engine exhaust was higher during the 16-h cycle than during the FTP cycle due to the one to three regeneration events observed during the 16-h cycle $\left(3.50 \times 10^{13} \pm 1.73 \times 10^{13} \mathrm{particle} / \mathrm{bhp}-\mathrm{h}\right)$ [13]. However, the particle number emissions were still about tenfold lower than those observed from a 2004-compliant (see Fig. 3). The peaks in particle number during the regeneration events, each lasting 30 to $45 \mathrm{~min}$, were roughly 10 to 100 times higher than the PM emissions when regeneration was not taking place [12]. The 2010-technology engines, on the other hand, did not trigger any active regeneration events during three repeated 16-h cycles; therefore, the reduction in particle number emission between the 2010 and the 2007 engines during the 16 -h cycle was $73 \%$. The 201016 -h cycle particle number/bhp-h was $9.30 \times 10^{12} \pm 5.74 \times 10^{12}$.

In exhaust of the 2007 engines, the number mean particle diameter measured during periods of the 16-h cycle without regeneration was $40 \mathrm{~nm}$, compared with $25 \mathrm{~nm}$ during periods with regeneration. In comparison, the number mean diameter in exhaust of a 2004 engine was $46 \mathrm{~nm}$ (Khalek et al. 2011 [13]). In exhaust of the 2010 engines, the number mean particle 
Table 2 Average emission rates of selected unregulated pollutants measured in ACES (16-h cycle)

\begin{tabular}{llll}
\hline Pollutant & $\begin{array}{l}\text { 2007 technology } \\
\text { engines }\end{array}$ & 2010 technology engines & $\begin{array}{l}\text { \% Change relative to 2007 } \\
\text { technology engines }\end{array}$ \\
\hline $\mathrm{NO}_{2}$ (g/bhp-h) & $0.73 \pm 0.20$ & $0.046 \pm 0.029$ & $-94 \%$ \\
$\begin{array}{l}\text { Particle number } \\
\text { (particle/bhp-h) }\end{array}$ & $3.5 \times 10^{13} \pm 1.73 \times 10^{13}$ & $9.30 \times 10^{12} \pm 5.740 \times 10^{12}$ & $-73 \%$ \\
$\mathrm{NH}_{3}$ (g/bhp-h) & $<0.0001$ & $0.0025 \pm 0.0014$ & $>+2400 \%$ \\
$\mathrm{CO}_{2}$ (g/bhp-h) & $590.2 \pm 22.7$ & $571.3 \pm 41.4$ & $\mathrm{~b}$ \\
$\mathrm{~N}_{2} \mathrm{O}$ (g/bhp-h) & $0.010 \pm 0.003$ & $0.073 \pm 0.030$ & $+630 \%$ \\
$\mathrm{CH}_{4}$ (g/bhp-h) & $0.0104 \pm 0.008$ & $<0.0001$ & $>-99 \%$ \\
$\mathrm{GWP}^{\mathrm{c}}$ & 593.2 & 592.8 & $\mathrm{~b}$ \\
\hline
\end{tabular}

Adapted from Khalek et al. [15]

${ }^{a}$ Data provided by Imad Khalek

${ }^{\mathrm{b}}$ No discernible change within the measurement uncertainties

${ }^{\mathrm{c}} \mathrm{GWP}=$ greenhouse warming potential based on $\mathrm{CO}_{2}, \mathrm{CH}_{4}$, and $\mathrm{N}_{2} \mathrm{O}$ emissions (unitless; see text for how it was calculated) diameter measured was $15 \mathrm{~nm}$ during the 16-h cycle (without regeneration) due to the higher efficiency of the DPF in removing solid particles.

There were several notable differences in PM composition among a 1998-compliant, the 2007 engines, and the 2010 engines (Fig. 4). EC, the major component of PM in 1998 engines (about $70 \%$ of the total mass of diesel PM), was substantially reduced in both the 2007 and 2010 engines (approximately 13 and $16 \%$, respectively). Also, whereas sulfate was the dominant component (53 \%) in PM emitted by 2007 engines, OC was the dominant component (66\%) in the PM from 2010 engines and sulfate was less than $1 \%$.

Introduction of urea as the reducing agent in SCR gave rise to the possibility of emissions of $\mathrm{NH}_{3}$ (the major product of urea decomposition and needed to reduce $\mathrm{NOx}$ ) or other urea

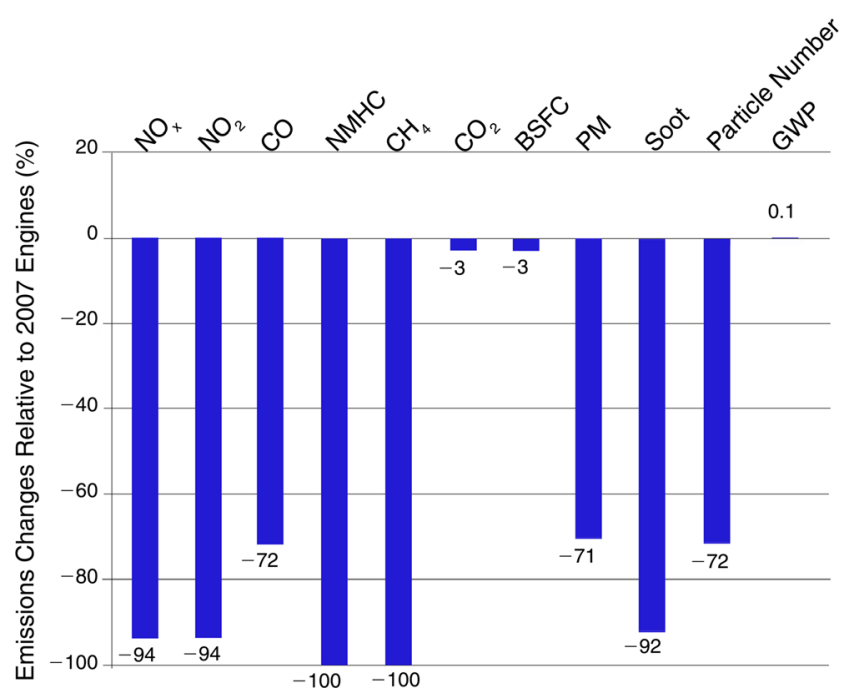

Fig. 2 Percent change in emissions from 2010 technology diesel engines relative to 2007 technology engine emissions measured during the 16-h cycle. $B S F C$ brake specific fuel consumption, GWP global warming potential (Khalek et al. 2013 [14]). Published with permission from the Health Effects Institute decomposition by-products or nitrogen-containing compounds that may be formed in the SCR or AMOX. The 2010-technology engines deploy the AMOX downstream of the SCR device to oxidize any unreacted $\mathrm{NH}_{3}$; however, it was important to measure how much $\mathrm{NH}_{3}$ may slip through the catalyst. Overall, $\mathrm{NH}_{3}$ emissions during the 16-h cycle were higher in Phase 2 than in Phase 1 (from less than 0.0001 to an average across the three engines of 0.0025 $\pm 0.0014 \mathrm{~g} / \mathrm{bhp}-\mathrm{h}$, corresponding to $0.82 \pm 0.49 \mathrm{ppm}$, see Table 2). Still, this level was much lower than the proposed European limit of $10 \mathrm{ppm}$. There is no $\mathrm{NH}_{3}$ emission standard in the USA. Out of the six urea-related compounds measured in the particle phase, only urea and cyanuric acid were detected during the 16-h cycle $(0.87 \pm 0.75$ and $9.0 \pm 9.0 \mu \mathrm{g} / \mathrm{bhp}-\mathrm{h}$,

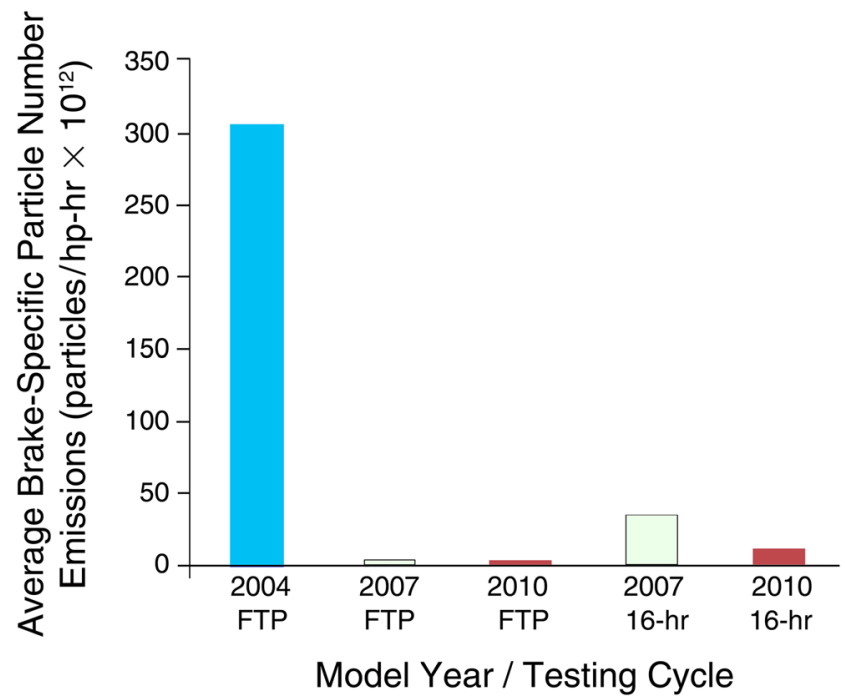

Fig. 3 Comparison of particle number emissions in exhaust from 2004(without any control technologies), 2007-, and 2010-technology diesel engines measured using the FTP cycle and the 16-h cycle. The means and standard deviations of the measurements are given in the "Results" section. Published with permission from the Health Effects Institute 
Fig. 4 PM composition for exhaust from 1998, 2007, and 2010 technology diesel engines. Published with permission from the Health Effects Institute

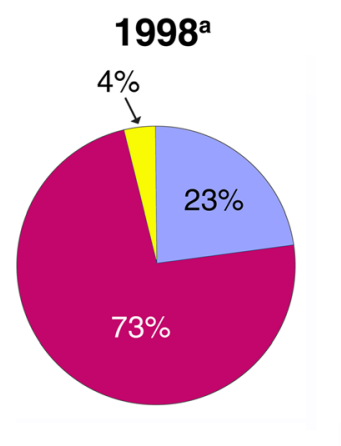

$2007^{b}$
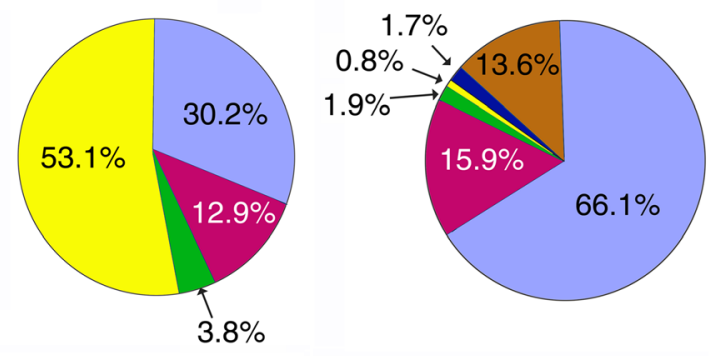

a Personal communication, Imad Khalek, 22 March 2012.

${ }^{\mathrm{b}}$ Adapted from Khalek et al. 2015.

respectively). This reflects a very low mass concentration $(9 \mathrm{ppb})$ of cyanuric acid in diesel engine exhaust [15].

\section{PHASE 3B}

This phase comprised the "core" bioassay, conducted in rats exposed to the exhaust from one of the 2007-complaint engines tested in Phase 1 via inhalation for up to 30 months. A back-up engine (MY 2008), referred to as B', was provided by the manufacturer and tested initially at Southwest Research Institute for overall performance and for detailed characterization of the regulated emissions. The engines were swapped during the course of the rat bioassay because of maintenance requirements.

To maximize the information obtained from exposed animals in Phase 3B, HEI funded "ancillary" studies to measure additional endpoints that are not normally part of long-term rodent bioassays. The (null) hypothesis for the study was that exposure to exhaust from a 2007-technology HHDDE would not cause an increase in tumor formation or have substantial toxic health effects in rats or mice, although some biological effects might occur.

\subsection{Methods}

Male and female 8-week-old Wistar Han rats (140 animals of each sex per exposure level, see Table 3) were exposed to clean air or to diluted exhaust at low, medium, and high exposure levels for $16 \mathrm{~h} /$ day 5 days/week for up to 30 months (lifetime exposure). In previous diesel inhalation studies, dilution ratios were based on particle mass concentrations. However, this approach was no longer feasible in ACES because of the low particle concentrations in the exhaust of the 2007-technology engines. $\mathrm{NO}_{2}$ was selected because it is the pollutant with the highest concentrations in the exhaust of the new engines and has been associated only with noncancer effects in previous rodent inhalation studies. In addition, a previous chronic inhalation study in rats provided guidance in choosing the $\mathrm{NO}_{2}$ target concentrations for ACES and provided results that the ACES results could be compared to [17]. Another consideration in the choice of the lowest dilution level (i.e., highest exhaust concentration) was to achieve an exposure chamber temperature that did not exceed the range recommended for rat inhalation studies $\left(18-26^{\circ} \mathrm{C}\right)$. The selected target concentrations of $\mathrm{NO}_{2}$ were 4.2 (high), 0.8 (mid), and $0.1 \mathrm{ppm}$ (low), and filtered air as a control. At these concentrations, the exhaust dilution ratios were approximately $25: 1,115: 1$, and 840:1, respectively.

The engine was operated on the 16-h cycle described above. Low-sulfur fuel was obtained from a local commercial supplier. The sulfur content was 3-5 ppm and the aromatic content was $25-28 \%$. The inhalation chamber air composition was characterized continuously for $\mathrm{NOx}, \mathrm{NO}_{2}, \mathrm{NO}, \mathrm{CO}$, $\mathrm{CO}_{2}$, PM, and black carbon (BC). In addition, once a week, PM mass was measured by gravimetric analysis, and PM number and size distribution were determined using a fastmobility particle sizer (FMPS) with a size range of 5 to $500 \mathrm{~nm}$. At the time of these measurements, PM mass was also measured at the inlet to the exposure chamber. A detailed intensive characterization of the gaseous and particulate phase compounds was conducted after 2.5, 11.5, and 24 months of exposure. The sampling and analytic methods were similar to those described for Phases 1 and 2, with the exception that $\mathrm{NO}_{2}$ was measured directly using a chemiluminescence analyzer, and particle number and size distribution were measured using a FMPS. For more details on the chamber exposure characterization, see Appendix 1 of [20].

Blood, lung lavage fluid, organs, and tissues were harvested at the various time points (10 animals of each sex per exposure group at $1,3,12$, and 24 months, and 100 rats of each sex per exposure group for the terminal sacrifice, as shown in Table 3). The terminal sacrifice was conducted after 28 months of exposure for surviving male rats and after 30 months of exposure for surviving female rats. The lungs and other organs and tissues were evaluated histologically at 
Table 3 Number of rats evaluated during the ACES 30month bioassay at each exposure level

\begin{tabular}{llllll}
\hline Assignment & \multicolumn{5}{l}{$\begin{array}{l}\text { Months after start of exposure } \\
\text { (males plus females) }\end{array}$} \\
\cline { 2 - 6 } & 1 & 3 & 12 & 24 & 28 and $30^{\mathrm{a}}$ \\
\hline $\begin{array}{l}\text { Intermediate sacrifice (biologic endpoints and histopathology) } \\
\text { Chronic bioassay (histopathology) }\end{array}$ & 20 & 20 & 20 & 20 & - \\
Cumulative total per exposure level & - & - & - & - & 200 \\
\hline
\end{tabular}

${ }^{\text {a }}$ Males were sacrificed at 28 months, females at 30 months each time point for the presence of tumors and other lesions. Other endpoints measured included pulmonary function and markers of oxidative stress, inflammation, and tissue injury in lung tissue and lung lavage fluid. The ancillary studies focused on markers of injury in the airways and other organs, markers of systemic inflammation and prothrombotic changes, and genotoxicity. Table 5 summarizes the methods for these and a few other noncancer endpoints by type of endpoint.

In addition to the chronic bioassay, ACES included a subchronic exposure study (up to 3 months) in mice. The results of this shorter-term study can be found in [19] and are not presented here. The results of Phase 3B were peer-reviewed by a panel of experts appointed by HEI prior to their publication as an HEI report [20]. The report was accompanied by a Commentary written by the panel.

\subsection{Results}

\subsubsection{Chamber Exposure Concentrations}

A summary of the results of the routine and detailed chamber air characterizations at each exposure level for the major pollutants or group of pollutants is provided in Table 4. More details can be found in [20]. Table 6 compares the average concentrations of PM, NOx, and $\mathrm{NO}_{2}$ in ACES with data from two older diesel bioassays [10, 18].

$\mathrm{CO}, \mathrm{NO}$, and $\mathrm{NO}_{2}$ accounted for most of the mass of the measured components. $\mathrm{NO}_{2}$ concentrations over the course of the study were within $10 \%$ of the target level. The ratio of $\mathrm{NO}_{2} / \mathrm{NOx}$ was on average 0.36 , lower than that measured in Phase 1 during the FTP cycle (0.6). This was due to an increase in NO later in the study, with a corresponding increase

Table 4 Summary of daily average concentrations of selected pollutants and groups of pollutants in the exposure chambers during the ACES 30month bioassay at each exposure level

\begin{tabular}{|c|c|c|c|c|}
\hline Exhaust components & Control & Low & Medium & High \\
\hline PM mass filter (in chamber), $\mu \mathrm{g} / \mathrm{m}^{3 \mathrm{a}}$ & $26.6 \pm 16.4$ & $24.9 \pm 15.6$ & $30.4 \pm 19.2$ & $30.5 \pm 15.6$ \\
\hline PM mass filter (at chamber inlet), $\mu \mathrm{g} / \mathrm{m}^{3 \mathrm{a}}$ & NA & $3.3 \pm 5.4$ & $5.1 \pm 4.4$ & $11.9 \pm 6.3^{\mathrm{b}}$ \\
\hline Particle number, particle $/ \mathrm{cm}^{3 \mathrm{a}}$ & $17,136 \pm 23,420$ & $215,225 \pm 412,549$ & $678,184 \pm 1,247,909$ & $828,814 \pm 1,041,925$ \\
\hline $\mathrm{NO}_{2}, \mathrm{ppm}^{\mathrm{a}}$ & $0.0 \pm 0.012$ & $0.1 \pm 0.02$ & $0.9 \pm 0.10$ & $4.2 \pm 0.4$ \\
\hline $\mathrm{NO}, \mathrm{ppm}^{\mathrm{a}}$ & $0.001 \pm 0.004$ & $0.4 \pm 0.3$ & $1.7 \pm 0.4$ & $7.5 \pm 1.9$ \\
\hline $\mathrm{NO}_{2} / \mathrm{NOx}\left(\mathrm{NO}+\mathrm{NO}_{2}\right)$ & $\mathrm{NC}$ & $\mathrm{NC}$ & $\mathrm{NC}$ & 0.36 \\
\hline $\mathrm{CO}, \mathrm{ppm}$ & $0.9 \pm 0.9^{\mathrm{b}}$ & $1.1 \pm 0.5^{\mathrm{b}}$ & $1.9 \pm 0.5^{\mathrm{b}}$ & $6.0 \pm 2.7^{\mathrm{a}}$ \\
\hline $\mathrm{EC}, \mu \mathrm{g} / \mathrm{m}^{3 \mathrm{~b}}$ & $0.4 \pm 0.4$ & $1.2 \pm 1.2$ & $0.4 \pm 0.4$ & $1.2 \pm 1$ \\
\hline $\mathrm{OC}, \mu \mathrm{g} / \mathrm{m}^{3 \mathrm{~b}}$ & $4.5 \pm 1.4$ & $6.6 \pm 1.4$ & $4.8 \pm 1.9$ & $5.7 \pm 2.4$ \\
\hline Sulfate, $\mathrm{ng} / \mathrm{m}^{3 \mathrm{~b}}$ & $101.6 \pm 26$ & $193.1 \pm 153.1$ & $644.8 \pm 405.5$ & $2,121.1 \pm 968.2$ \\
\hline Nitrate, $\mathrm{ng} / \mathrm{m}^{3 \mathrm{~b}}$ & $18.6 \pm 16.7$ & $181.2 \pm 195.9$ & $220.2 \pm 73.9$ & $2,087.3 \pm 747$ \\
\hline Elements, $\mathrm{ng} / \mathrm{m}^{3 \mathrm{~b}}$ & $461.3 \pm 208.5$ & $567.9 \pm 224$ & $661 \pm 302.1$ & $811.5 \pm 336.3$ \\
\hline $\mathrm{PAH}, \mu \mathrm{g} / \mathrm{m}^{3 \mathrm{~b}}$ & $0.8 \pm 0.5$ & $1.1 \pm 0.4$ & $1.9 \pm 0.7$ & $4.7 \pm 1.6$ \\
\hline Carbonyls, $\mu \mathrm{g} / \mathrm{m}^{3 \mathrm{~b}}$ & $53.8 \pm 12.1$ & $71.2 \pm 40.2$ & $21.4 \pm 5.1$ & $1 \pm 1.5$ \\
\hline $\mathrm{VOC}, \mu \mathrm{g} / \mathrm{m}^{3 \mathrm{~b}}$ & $33.5 \pm 21.3$ & $50.3 \pm 31.3$ & $44.2 \pm 15.3$ & $148.9 \pm 96.9$ \\
\hline
\end{tabular}

$N A$ not available (no data were collected during the study as per the study protocol), $N C$ not calculated, given the low concentrations

${ }^{a}$ Hourly averages over the entire rat bioassay (data are taken from Table 3B of [20])

${ }^{\mathrm{b}}$ Averages during a 16-h exposure period of four detailed intensive characterizations, three of exhaust from engine B' and one from exhaust from engine B. The first of the four characterizations was conducted during the short-term study in mice (data are taken from Appendix 1 of [20]) 
in NOx. However, the $0.36 \mathrm{NO}_{2} / \mathrm{NOx}$ ratio was substantially higher than that found in the earlier rat diesel bioassays (between 0.11 and 0.16) (see Table 6). Conversely, the $\mathrm{PM} / \mathrm{NO}_{2}$ ratio was much smaller.

At the high exposure level, PM mass measured at the exposure chamber inlet was $8 \mu \mathrm{g} / \mathrm{m}^{3}$ on average, while the PM mass inside the chambers averaged $17-27 \mu \mathrm{g} / \mathrm{m}^{3}$ across the exposure levels. By taking measurements of PM mass at both the chamber inlet and inside the chamber, the investigators determined that more than half of the PM mass in the chamber was contributed by the animals (e.g., from their dander or food supply). The ratio of PM to NOx in the chamber was much lower than that in the earlier diesel bioassays, as shown in Table 6.

Both particle mass and particle number were measurable primarily during the regeneration periods. A typical average concentration was $50 \mu \mathrm{g} / \mathrm{m}^{3}$ in the chamber. Both PM mass concentration at the chamber inlet and the particle number concentrations inside the chamber were dilution-dependent, indicating that these particles were derived from the engine. The particle number size distribution measured in the chamber was approximately $20 \mathrm{~nm}$, consistent with the results of Phase 1 (see Appendix I of [20]). Approximately $50 \%$ of the mass at the high exposure levels was carbon. Most of the remainder of the mass consisted of nitrate, ammonium, sulfate, and the elements zinc, manganese, copper, and iron.

Concentrations of VOCs were very low. The concentration of carbonyls was lower at the medium and high exposure levels than for the control (filtered air) exposure. This was attributed to chemical reactions with NOx that occurred at the time the samples were taken.

\subsubsection{Histopathology in Rats after Lifetime Exposures}

Chronic exposure to exhaust from a 2007-technology engine did not induce tumors or precancerous changes in the rat lung (Fig. 5) and did not increase tumor incidence in any tissue outside the lungs. Some mild histological changes were found in the lung-periacinar epithelial hyperplasia, bronchiolization, and accumulation of macrophages - that were confined to a small region, the centriacinus, which is involved in gas exchange. Some fibrotic tissue changes, also confined to the centriacinar region, were noted. Histological changes were detected in the lungs of male and female rats as early as 3 months after the start of exposure in the high exposure group only. Detailed results of this study can be found in [20]. For a summary, see Table 5.

HEI convened a panel of expert pathologists, the Pathology Working Group (PWG), to evaluate the histopathology data collected. The PWG findings confirmed the major histopathologic observations reported by the investigators. In addition, the PWG reviewed the findings of this study side by side with findings from relevant prior long-term studies of exposure to exhaust from older diesel engines and to oxidant gases that

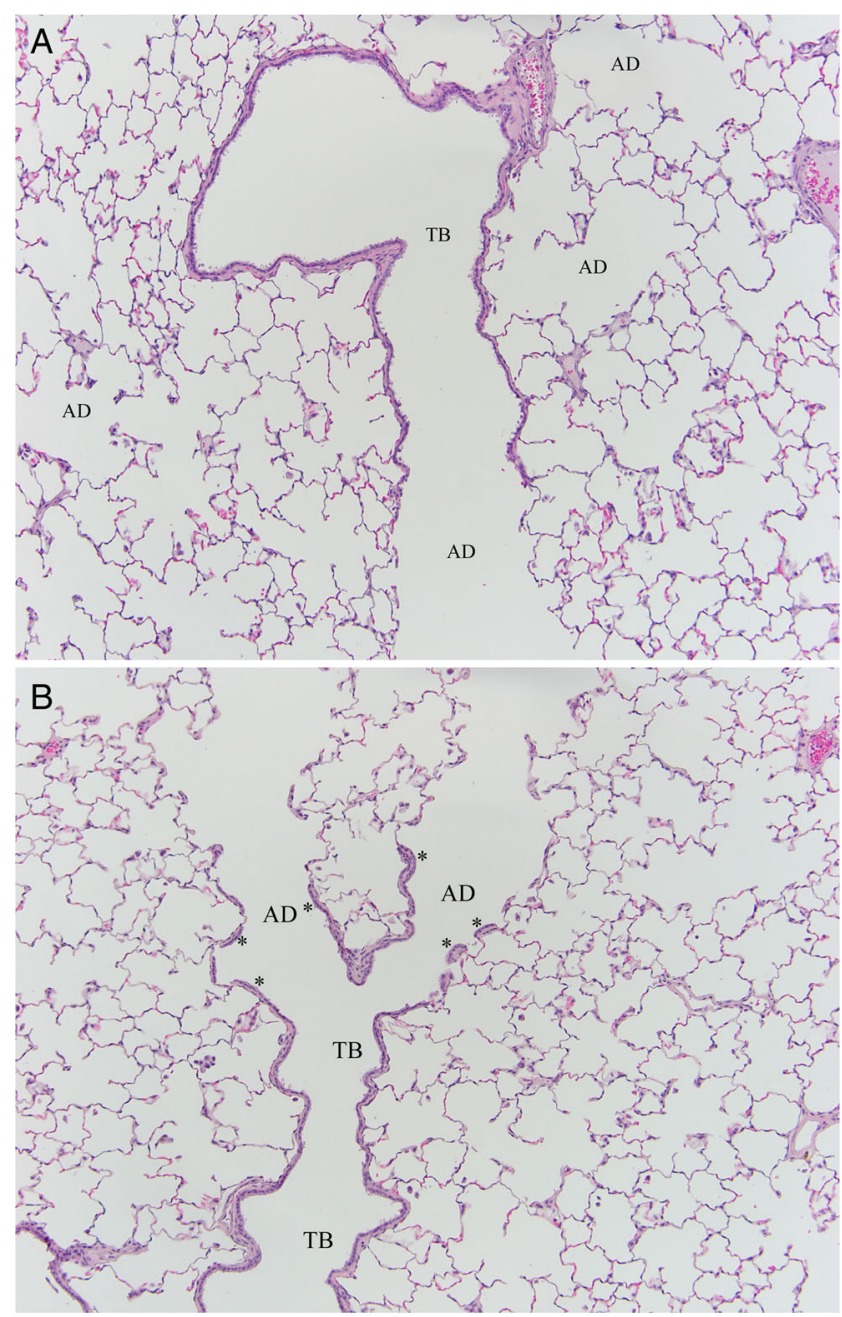

Fig. 5 Effects in the lungs of female Wistar Han rats exposed for 30 months to exhaust from a 2007 diesel engine in ACES. a Control exposure (to filtered air), showing a normal rat lung with a terminal bronchiole (TB) opening downward and ending with an alveolar duct (AD) opening into alveolar spaces. Other alveolar ducts and alveoli surround the larger airway. In contrast to Fig. 5b, there is no thickening of the alveolar duct interstitium or alveolar walls, nor are they lined by an increase in cuboidal epithelial cells. b High level exposure to 2007 engine exhaust (4.2 ppm $\mathrm{NO}_{2}$ and $0.027 \mathrm{mg} / \mathrm{m}^{3} \mathrm{PM}$ ), showing a terminal bronchiole dividing into two alveolar ducts that exhibit a very minimal increase in thickening of the walls of the ducts, which are lined with a minimal increase in cuboidal nonciliated epithelial cells where the walls are thickened by increased collagen (asterisk). These changes were found only at the highest exposure level. Original magnification $\times 100$ [20]. Published with permission from the Health Effects Institute

provided a context with which to compare and contrast the current study findings. The overall conclusions of the comparative review by the PWG were that chronic exposure to 2007 engine exhaust did not produce tumors in the lung in rats and resulted in effects that differed markedly from the chronic effects of exposure to exhaust from older (pre-1998) diesel engines observed in multiple rat studies, where lung tumors were observed, as well as inflammation and the deposition of soot in the lung (see for example histopathology at 30 months of exposure in [10] [Fig. 6] and at 24 months in [18]). The PWG 


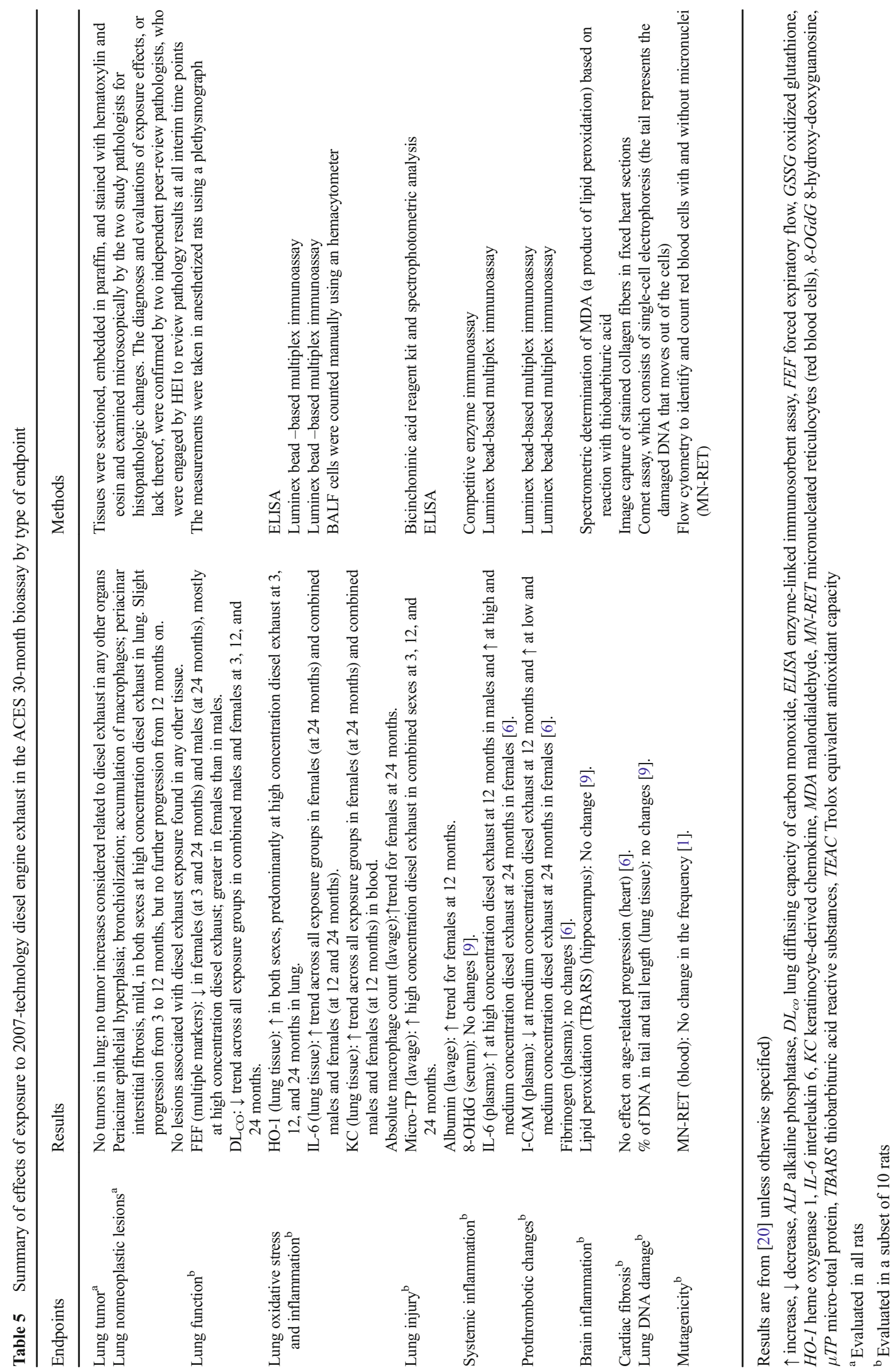


concluded that effects of the 2007 engine exhaust in the lung over the entire exposure duration more closely resembled changes noted after long-term exposure to gaseous oxidant pollutants, in particular $\mathrm{NO}_{2}$ (Fig. 7; [16, 17]).

\subsubsection{Other Endpoints in Rats after Lifetime Exposures}

When lung function was evaluated, decreases in some measures of flow-including peak expiratory flow, forced expiratory flow between 25 and $50 \%$ of forced vital capacity, and maximal mid-expiratory flow-were detected in female rats exposed for 3 months to the high concentration of NTDE for 3 months. The diffusing capacity of $\mathrm{CO}$ in the lung (a measure of alveolar-capillary gas exchange) showed a small decrease in male and female rats as a result of the exposure (see Table 5).

Among the large number of biological endpoints evaluated in rats exposed to 2007 engine exhaust for up to 28 months (males) and 30 months (females) in lung tissue and lavage fluid, and blood, only a few showed exposure-associated changes. Results for a subset of endpoints representative of the types of endpoints examined in ACES are provided in Table 5. Briefly, small increases were noted in some markers of lung oxidative stress and inflammation (heme oxygenase-1 [HO-1], interleukin6 [IL-6], keratinocyte-derived chemokine [KC], micro-total protein, total white blood cells, and macrophages in the lung, see [20]). In addition, some mild lung tissue injury, indicated by an increase in micro-protein, was observed in both sexes combined

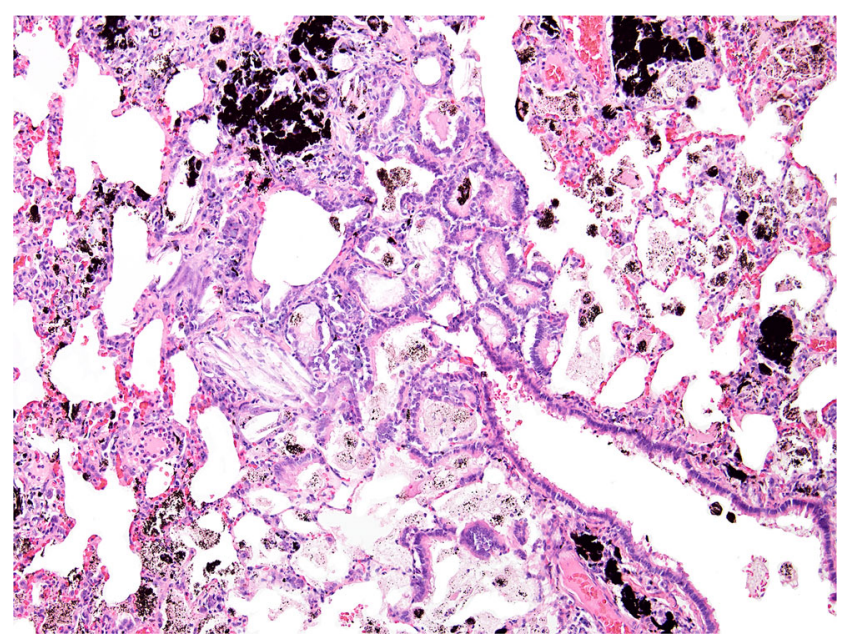

Fig. 6 Effects in lungs of female Wistar Han rats exposed for 30 months to exhaust from a pre-1998 light duty diesel engine (at $1.5 \mathrm{ppm} \mathrm{NO}$ and $2.8 \mathrm{mg} / \mathrm{m}^{3} \mathrm{PM}, 19 \mathrm{~h} /$ day) [9]. Prominent black diesel soot particulates are present free in alveoli, in the numerous pulmonary alveolar macrophages, and in interstitial tissues. Marked centriacinar epithelial hyperplasia and bronchiolization occurred. Marked chronic inflammation also occurred, characterized by a mixed inflammatory cell infiltrate, fibrosis, and some sterol cleft formation. The entire lung was involved, and this picture is dramatically different from what was found in ACES Phase 3B (see Fig. 5b). Original magnification $\times 100$ [10]. Courtesy of Ernst Heinrich; photography by Rodney Miller. Published with permission from the Health Effects Institute

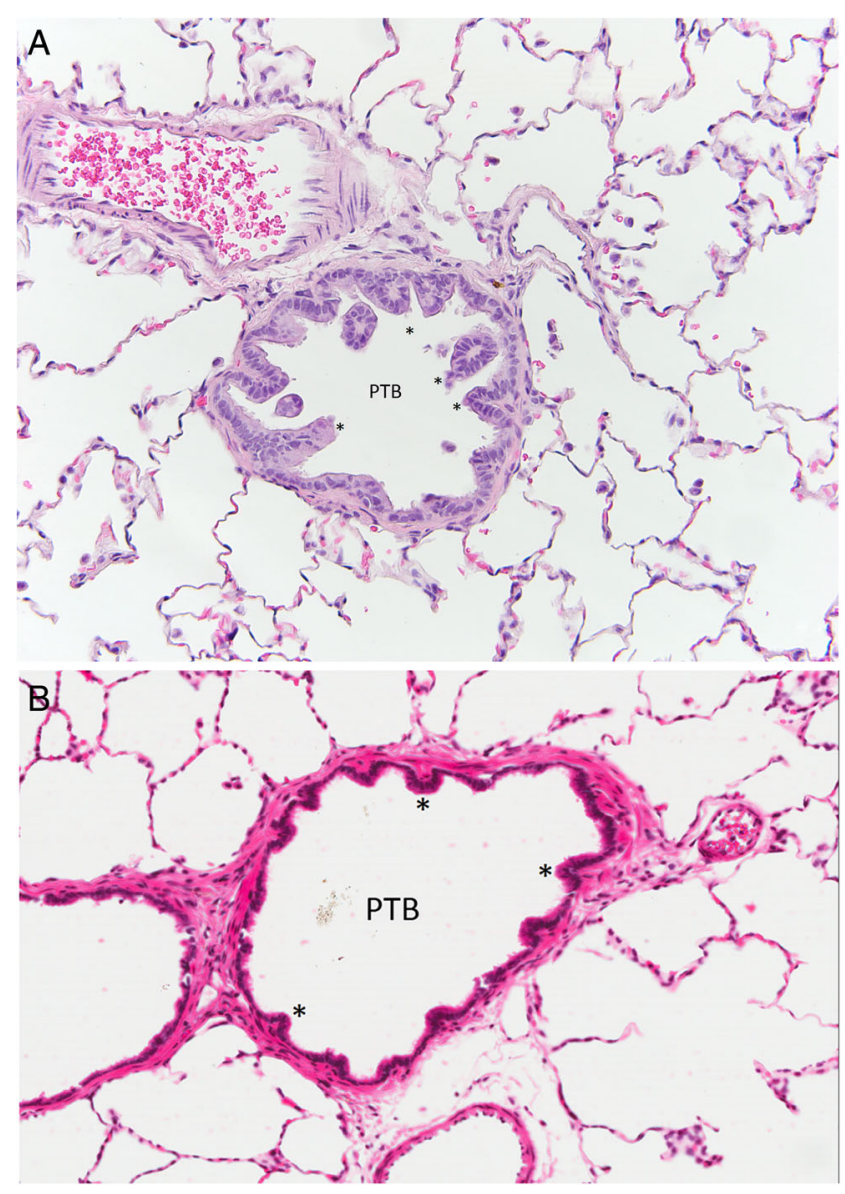

Fig. 7 Comparison of effects in lungs of rats exposed to exhaust from a 2007 diesel engine (in ACES) or to $\mathrm{NO}_{2}$ alone, showing similar effects in the lungs. a Effects in lungs of male Wistar Han rats exposed for 28 30 months to exhaust from a 2007 engine in ACES (high level exposure at $4.2 \mathrm{ppm} \mathrm{NO}$ and $0.0273 \mathrm{mg} / \mathrm{m}^{3} \mathrm{PM}, 16 \mathrm{~h} /$ day) [20]. Preterminal bronchiole (PTB) showing epithelial hyperplasia accompanied by papillary projections (asterisk) into the bronchiole that was found in some rats exposed only to the highest concentration of diesel exhaust. b In male, Fischer 344 rats exposed for 24 months to $\mathrm{NO}_{2}$ (at $9.5 \mathrm{ppm}, 6 \mathrm{~h} /$ day) [17]. PTB showing epithelial cell crowding, similar to what is shown in Fig. 7a, but with less inward projection of the epithelium. These changes were uncommon in the $\mathrm{NO}_{2}$ study by Mauderly and colleagues in F344 rats but were seen more often in the 1987 study by Kubota and colleagues in Wistar Han rats that were exposed to $4 \mathrm{ppm} \mathrm{NO}$ for 27 months (not shown). Original magnification $\times 200$. Published with permission from the Health Effects Institute

at 3,12, and 24 months of exposure. This change was paralleled by an increase in albumin in lung lavage fluid. There was also an increase in plasma IL-6, and small increases after 1 and 3 months (but no changes at later time points) in 8-hydroxydeoxyguanosine (8-OHdG), which is considered a product of oxidative damage and also a marker of DNA damage [9].

Exposure of rats to 2007 engine exhaust for up to 24 months was not associated with genotoxic changes, as measured in peripheral blood as the frequency of micronuclei-containing reticulocytes [1], and as DNA tail length and tail moment in the comet assay [9]. Exposure 
Table 6 Comparison of daily average concentrations of $\mathrm{PM}, \mathrm{NO}_{2}$, and $\mathrm{NO}_{\mathrm{x}}$ in the high exposure chambers during chronic bioassays in rats exposed to diesel exhaust

\begin{tabular}{|c|c|c|c|c|c|c|}
\hline Study & $\begin{array}{l}\text { Dilution } \\
\text { ratio }\end{array}$ & $\begin{array}{l}\text { PM mass } \\
\text { gravimetric } \\
\left(\mathrm{mg} / \mathrm{m}^{3}\right)\end{array}$ & $\begin{array}{l}\mathrm{NO}_{2} \\
(\mathrm{ppm})\end{array}$ & $\begin{array}{l}\mathrm{NO}_{x} \\
(\mathrm{ppm})\end{array}$ & $\begin{array}{l}\mathrm{PM} / \mathrm{NO}_{2} \\
\text { (ratio) }\end{array}$ & $\begin{array}{l}\mathrm{NO}_{2} / \mathrm{NO}_{\mathrm{x}} \\
(\%)\end{array}$ \\
\hline $\begin{array}{l}\text { ACES Phase 3B [20] (2007,14-L heavy-duty diesel engine and ultra- } \\
\text { low sulfur fuel) }\end{array}$ & $25: 1$ & 0.030 & 4.2 & 11.7 & 0.07 & 36 \\
\hline $\begin{array}{l}\text { Mauderly et al. } 1994 \text { [18] (1988, 6.2-L light-duty diesel engine and high } \\
\text { sulfur fuel) }\end{array}$ & NR & 6.33 & 3.8 & 23.5 & 1.7 & 16 \\
\hline $\begin{array}{l}\text { Heinrich et al. } 1995 \text { [11] (1.6 L light-duty diesel engine }{ }^{\mathrm{a}} \text { and high sulfur } \\
\text { fuel) }\end{array}$ & $9: 1$ & 6.98 & 3.8 & 33.1 & 1.8 & 11 \\
\hline
\end{tabular}

$N R$ not reported

${ }^{\text {a }}$ Age of the engine not reported

to the 2007 engine exhaust for 24 months also did not induce lipid peroxidation in the hippocampus (as measured by TBARs, see [9]). There were no changes of prothrombotic markers (such as I-CAM and fibrinogen) and cardiac effects (such as cardiac fibrosis, see [6]).

\section{Discussion and Conclusions}

The results of ACES show that the aftertreatment technologies used in 2007 and 2010-technology diesel engines are highly effective and that they meet - and exceed - the emissions reductions mandated by US regulations. The ACES study confirms the effectiveness of the DOC/DPF system in greatly reducing PM mass and number emissions and of SCR/AMOX system in reducing $\mathrm{NOx}$ emissions (both $\mathrm{NO}$ and $\mathrm{NO}_{2}$ ); similarly, emissions of more than 300 other compounds - some with known carcinogenic and toxic properties - measured in the exhaust were also reduced relative to exhaust from pre-2007 diesel engines. Engine testing in ACES was performed using the usual certification (FTP) test cycle, as well as a more demanding 16-h cycle, developed especially for the ACES program, that better represents real-world driving conditions and gives greater confidence in the relevance of the emissions testing results.

The notable difference in the PM composition between the 2007- and the 2010-technology engines was the virtual absence of sulfate in exhaust of the 2010-technology engines and, to a lesser degree, the increase in ammonium and nitrate inorganic ions that can be produced by the urea-based SCR system. The storage of sulfur at the surface of DOC/DPF/SCR/AMOX aftertreatment and the lack of high-temperature active regeneration may be responsible for the very low sulfate emissions from 2010-technology engines. With 2007-technology engines, the DPFs regenerated at least one to three times during a 16-h cycle, causing a rise in DOC and DPR temperatures that led to sulfate desorption. The lack of regeneration with the 2010-technology engines may be associated with less sulfate formation and improved elemental carbon and particle number efficiency, since the loaded DPFs typically provide better efficiencies. Future testing with 2010-technology engines should shed some light on the effects of DPF regeneration on the average emissions from these engines.

Studies that have examined emissions under present realworld conditions from individual vehicles have reported reductions in PM and NOx emissions as the proportion of new or retrofitted diesel engines increases, showing the effectiveness of in-use DPFs as well as of SCR [3, 4, 21]. However, it should be noted that the test conditions, by necessity of short duration, did not address the durability of the emission controls over the life of the engines. As with the introduction of any new technology on a large scale in the marketplace, some challenges with the use of the new aftertreatment technologies have been observed. First, although DPFs are very effective, some recent reports suggest that, under real-world conditions, a small proportion of newtechnology engines still produce higher emissions of PM $[4,7]$. Starting with 2016 model year, HHDDE vehicles are equipped with onboard diagnostics (OBD) and with $\mathrm{PM}$ and $\mathrm{NO}_{\mathrm{X}}$ sensors to help monitor the effectiveness of the aftertreatment system, and these trigger a malfunction indicator light when the emissions exceed regulatory OBD threshold. Regarding the SCR technology, elevated $\mathrm{NO}_{2}$ emissions have been noted when the SCR device does not operate effectively, for example, during cold-start, low-load conditions, and during stop-and-go driving, when the exhaust is not sufficiently hot to allow optimum SCR function $[8,21]$. This limitation of the SCR device is being observed at a time when there is a strong interest in even greater $\mathrm{NO}_{2}$ controls in some areas in the USA that are out of compliance with the ozone or $\mathrm{NO}_{2}$ ambient standards, or both. Engine and aftertreatment technology manufacturers are developing new and supplemental approaches to address this problem.

The ACES study confirmed the hypothesis that exposure would not cause an increase in tumor formation although some biological effects might occur. Histopathological analysis of lung tissue of rats exposed for a lifetime to the exhaust from a 2007-technology engine showed mild remodeling in the centriacinar region of the lung, but no tumors. These results differ from those observed in earlier bioassays in which rats were exposed to traditional technology diesel exhaust 
from older engines, which have shown to cause lung tumors under similar conditions (Table 6). The few effects observed in the ACES study were consistent with changes noted after exposure to $\mathrm{NO}_{2}$ alone [17]. However, it is possible that components of 2007 engine exhaust other than $\mathrm{NO}_{2}$ may have contributed to the reported effects, but their low concentrations suggest that they are unlikely to be primarily responsible. As noted above, $\mathrm{NO}_{2}$ was a pollutant present in 2007 engine emissions that was greatly reduced in exhaust from 2010 engines, which deployed a selective catalytic reduction system for NOx control.

The majority of the large number of biological response indicators measured was unchanged with exposure to exhaust from a 2007 engine. Among the few changes observed were small increases in a few markers of oxidative stress and inflammation-HO-1, IL-6, KC, $\mu \mathrm{TP}$, total white blood cells, and macrophages - that were detected in lung tissue, lung lavage fluid, and blood. Analyses of inflammatory and prothrombin markers in plasma suggested some small changes at some time points, especially in females, but their pathophysiologic significance remains unclear. No exposure-related genotoxic effects and DNA oxidative damage were seen in peripheral blood up to 24 months of exposure. However, the genotoxic endpoints measured are relatively short-term and limit the interpretation of these negative findings. Small decreases in measures of expiratory flow were observed, predominantly at the highest exposure level and in females, that were consistent with histopathologic findings in the gas exchange region.

It should be noted again that Phase 3 of ACES used the minimum exhaust dilution feasible given exhaust temperature restrictions and the need to avoid serious chronic health effects and mortality due to exposure to $\mathrm{NO}_{2}$ and $\mathrm{CO}$. The particle mass concentration under these conditions was very low due the use of the DPF, i.e., around $30 \mu \mathrm{g} / \mathrm{m}^{3}$, half of which was attributed to animal dander and feed.

Results of long-term rat bioassays, such as ACES Phase $3 \mathrm{~B}$, are used - in combination with results of human epidemiologic studies - by various organizations and regulatory agencies to assess the likelihood that a compound or a mixture of compounds may cause cancer in humans. Studies in rats exposed to exhaust from TDE have provided supporting evidence for observations made in studies of workers that were occupationally exposed to diesel exhaust, leading the International Agency for Research on Cancer (IARC, a branch of the World Health Organization), to classify diesel engine exhaust as a "known human carcinogen" (Group 1, see [2]). The IARC review noted that the animals studies reviewed had used exhaust "generated from fuels and diesel engines produced before 2000" and the substantially reduced emissions associated with advances in diesel technology in the past 2 decades. The ACES results are expected to provide useful data for future assessments of the carcinogenicity of diesel exhaust.
In summary, the ACES results demonstrate the effectiveness of aftertreatment technologies used in modern 2007- and 2010-technology diesel engines: They greatly reduce the emissions of $\mathrm{PM}, \mathrm{NOx}$, and $\mathrm{NO}_{2}$, and the levels of other toxic components of these engines when tested in the laboratory, using both the FTP cycle and a more demanding test cycle. After a lifetime of exposure, exposure to a 2007-technology engine exhaust did not produce tumors in rats-unlike exhaust from older diesel engines - demonstrating the effectiveness of DPFs in reducing the exhaust toxicity. The ACES results hold promise for developing countries, although a lack of resources and availability of low-sulfur fuel have hampered implementation of diesel emissions regulations worldwide. Many countries, including Mexico, China, and India, are now taking steps to implement new fuel standards that will enable them to reduce diesel emissions by adopting newtechnology diesel engines. It is hoped that other countries will follow with similar actions and that, as a result, the adverse health effects of exposure to diesel emissions will begin to be reduced worldwide.

Acknowledgments We acknowledge Chris Tennant and Geoffrey Sunshine for their contributions to the ACES project, and Jeffrey Bemis, Lance Hallberg, and Daniel Conklin for their role as principal investigators of the Phase $3 \mathrm{~B}$ ancillary studies.

Financial support for ACES Phases 1 and 2 was provided by the U.S. Department of Energy (DOE) Office of Vehicle Technologies through the National Renewable Energy Laboratory, the Engine and Truck Manufacturers Association (EMA), the American Petroleum Institute, and the Manufacturers of Emission Controls Association. Financial support for ACES Phase 3 was provided by EPA, EMA, and CARB. In addition, we acknowledge Caterpillar, Cummins, Detroit Diesel, and Volvo Powertrain for contributing the engines, and Lubrizol for providing the lube oil.

Although this study was conducted with partial funding from DOE and EPA, this document has not been subjected to the Department's and Agency's peer and administrative review, respectively, and therefore may not reflect the view of the Department or the Agency and no official endorsement by them should be inferred. Also, the content of this document has not been reviewed by private party institutions, including those that support the Health Effects Institute; therefore it may not reflect the views or policies of these parties and no endorsement by them should be inferred.

\section{References}

1. Bemis, J.C., Torous, D.K., Dertinger, S.D.: Part 2. Assessment of micronucleus formation in rats after chronic exposure to newtechnology diesel exhaust in the ACES bioassay. In: McDonald, J.D., Bemis, J.C., Hallberg, L.M., Conklin, D.J. (eds.) Advanced Collaborative Emissions Study (ACES): Lifetime Cancer and NonCancer Assessment in Rats Exposed to New-Technology Diesel Exhaust. Health Effects Institute, Boston (2015). Research Report 184

2. Benbrahim-Tallaa, L., Baan, R.A., Grosse, Y., Lauby-Secretan, B., El Ghissassi, F., Bouvard, V., et al.: Carcinogenicity of dieselengine and gasoline-engine exhausts and some nitroarenes. Lancet Oncol. 13(7), 663-664 (2012) 
3. Bishop, G.A., Schuchmann, B.G., Stedman, D.H.: Heavy-duty truck emissions in the South Coast Air Basin of California. Environ. Sci. Technol. 47, 9523-9529 (2013)

4. Bishop, G.A., Hottor-Raguindin, R., Stedman, D.H., McClintock, P., Theobald, E., Johnson, J.D., et al.: On-road heavy-duty vehicle emissions monitoring system. Environ. Sci. Technol. 49, 16391645 (2015)

5. Clark, N.N., Zhen, F., Bedick, C., Gautam, M., Wayne, W., Thompson, G., et al.: Creation of the 16-hour engine test schedule from the heavy heavy-duty diesel engine test schedule. Coordinating Research Council, Alpharetta (2007). CRC Report No. ACES-1a. Avail- able at www.crcao.org/publications/emissions/index.html Accessed 5 Aug 2016

6. Conklin, D.J., Kong, M.: Part 4. Assessment of plasma markers and cardiovascular responses in rats after chronic exposure to new-technology diesel exhaust in the ACES bioassay. In: Advanced Collaborative Emissions Study (ACES): Lifetime Cancer and Non- Cancer Assessment in Rats Exposed to New-Technology Diesel Exhaust. Research Report 184. Boston, MA, Health Effects Institute (2015)

7. Envirotest Canada: Greater Vancouver Regional District: Remote Sensing Device Trial for Monitoring Heavy-Duty Vehicle Emissions. Burnaby, British Columbia. Available at www.metrovancouver. org/services/air-quality/AirQualityPublications/2013_RSD_HDV Study.pdf Accessed 5 Aug 2016 (2013)

8. Franco, V., Sánchez, F.P., German, J., Mock, P.: Real-world exhaust emissions from modern diesel cars: a meta-analysis of PEMS emissions data from EU (Euro 6) and US (Tier 2 Bin5/ULEV II) diesel passenger cars. International Council on Clean Transportation, San Francisco (2014). White Paper

9. Hallberg, L.M., Ward, J.B., Hernandez, C., Ameredes, B.T., Wickliffe, J.K.: Part 3. Assessment of genotoxicity and oxidative damage in rats after chronic exposure to new-technology diesel exhaust in the ACES bioassay. In: McDonald, J.D., Bemis, J.C., Hallberg, L.M., Conklin, D.J. (eds.) Advanced Collaborative Emissions Study (ACES): Lifetime Cancer and Non-Cancer Assessment in Rats Exposed to New-Technology Diesel Exhaust. Health Effects Institute, Boston (2015). Research Report 184

10. Heinrich, U., Muhle, H., Takenaka, S., Ernst, H., Fuhst, R., Mohr, U., et al.: Chronic effects on the respiratory tract of hamsters, mice and rats after long-term inhalation of high concentrations of filtered and unfiltered diesel engine emissions. J. Appl. Toxicol. 6, 383-395 (1986)

11. Heinrich, U., Fuhst, R., Rittinghausen, S., Creutzenberg, O., Bellmann, B., Koch, W., et al.: Chronic inhalation exposure of Wistar rats and two different strains of mice to diesel engine exhaust, carbon black, and titanium dioxide. Inhal. Toxicol. 7, 533556 (1995)

12. Khalek, I.A., Bougher, T.L., Merritt, P.M.: Phase 1 of the advanced collaborative emissions study. Coordinating Research Council, Alpharetta (2009). CRC Report: ACES Phase 1. Available at www.crcao.org/publications/emissions/index.html [accessed 5 Aug 2016]

13. Khalek, I.A., Bougher, T.L., Merritt, P.M., Zielinska, B.: Regulated and unregulated emissions from highway heavy-duty diesel engines complying with U.S. Environmental Protection Agency 2007 emissions standards. J. Air Waste Manag. Assoc. 61, 427-442 (2011)

14. Khalek, I.A., Blanks, M.G., Merritt, P.M.: Phase 2 of the advanced collaborative emissions study. Coordinating Research Council, Alpharetta (2013). CRC Report: ACES Phase 2 Available at www.crcao.org/publications/emissions/index.html [Accessed 5 Aug 2016]

15. Khalek, I.A., Blanks, M.G., Merritt, P.M., Zielinska, B.: Regulated and unregulated emissions from modern 2010 emissions-com- pliant heavy-duty on-highway diesel engines. J. Air Waste Manag. Assoc. 65(8), 987-1001 (2015)

16. Kubota, K., Murakami, M., Takenaka, S., Kawai, K., Kyono, H.: Effects of long-term nitrogen dioxide exposure on rat lung: morphological observations. Environ. Health Perspect. 73, 157-169 (1987)

17. Mauderly, J.L., Bice, D.E., Cheng, Y.S., Gillett, N.A., Henderson, R.F., Pickrell, J.A., et al.: Influence of experimental pulmonary emphysema on the toxicological effects from inhaled nitrogen dioxide and diesel exhaust. Health Effects Institute, Cambridge (1989). Research Report 30

18. Mauderly, J.L., Snipes, M.B., Barr, E.B., Belinsky, S.A., Bond, J.A., Brooks, A.L., et al.: Part I: Neoplastic and nonneoplastic lung lesions. In: Pulmonary toxicity of inhaled diesel exhaust and carbon black in chronically exposed rats. Research Report 68. Cambridge, Health Effects Institute (1994)

19. McDonald, J.D., Doyle-Eisele, M., Gigliotti, A., Miller, R.A., Seilkop, S., Mauderly, J.L., et al.: Part 1. Biologic responses in rats and mice to subchronic inhalation of diesel exhaust from U.S. 2007-compliant engines: report on 1, 3-, and 12-month exposures in the ACES bioassay. Health Effects Institute, Boston (2012). Research Report 166

20. McDonald, J.D., Doyle-Eisele, M., Seagrave, J., Gigliotti, A.P., Chow, J., Zielinska, B., et al.: Part 1. Assessment of carcinogenicity and biologic responses in rats after lifetime inhalation of newtechnology diesel exhaust in the ACES bioassay. In: Advanced Collaborative Emissions Study (ACES) Lifetime Cancer and Non-Cancer Assessment in Rats Exposed to New-Technology Diesel Exhaust. Research Report 184. Boston, Health Effects Institute (2015)

21. Misra, C., Collins, J.F., Herner, J.D., Sax, T., Krishnamurthy, M., Sobieralski, W., et al.: In-use NOx emissions from model year 2010 and 2011 heavy-duty diesel engines equipped with aftertreatment devices. Environ. Sci. Technol. 47, 7892-7898 (2013)

22. Preble, C.V., Dallmann, T.R., Kreisberg, N.M., Hering, S.V., Harley, R.A., Kirchstetter, T.W.: Effects of particle filters and selective catalytic reduction on heavy-duty diesel drayage truck emissions at the Port of Oakland. Environ. Sci. Technol. 49, 8864-8871 (2015)

23. U.S. Environmental Protection Agency: Control of air pollution from new motor vehicles: heavy-duty engine and vehicle standards and highway diesel fuel sulfur control requirements; final rule. Fed. Reg. 66, 5002-5193 (2001) 